\title{
PENGARUH PEMBELAJARAN MATEMATIKA BERBASIS KONSTRUKTIVISME DENGAN MODEL KOOPERATIF TIPE TIME ASSISTED INDIVIDUALIZATION (TAI) PADA HASIL BELAJAR SISWA SEKOLAH DASAR
}

\author{
Suparman \\ Sri Hardjo \\ Kasni Astutik \\ e-mail: suparman@ecampus.ut.ac.id
}

\begin{abstract}
This research is a development research to describe the impact of constructivism-based learning with TAl type co-operative model of triangle material on student learning outcomes. Analysis of the data is based on (1) descriptive analysis of validator's on instructional devices, (2) average learners'activity during learning, (3) average learners' response to learning, (4) average observation ability (6) analysis of the effectiveness of constructivismbased learning with TAl-type cooperative model which includes: (a) comparation of learning result with the minimum mastery requirement using one sample t-test, (b) classical test, and (c) the influence of learners activity on learners' learning result using simple linear regression. The result shows that the validator's evaluation on learning tool is very good, whereas the other findings are as follows: the average of students' learning result is 78,87 higher than the minimum mastery requirement, which is 65 , all students meet the minimum requirement for mastery, and the majority of students are active (with a mean of 4,01), the ability of teachers in managing learning in the category is very good $(M=4,07)$, the activities of learners in the learning process contributes $75,1 \%$ to the learning result. Thus, it can be concluded thatconstructivism-based mathematics learning modelwith TAl type cooperative model is effective to produce better active learning and result.
\end{abstract}

Keywords: constructivism, co-operative model, development method, learning tool, timeassisted individualization

\footnotetext{
ABSTRAK

Penelitian ini merupakan penelitian pengembangan untuk mendeskripsikan dampak pembelajaran berbasis konstruktivisme dengan model kooperatif tipe TAl materi segitiga pada hasil belajar siswa. Analisis data yang digunakan: (1) analisis deskriptif hasil penelitian validator terhadap perangkat pembelajaran, (2) rata-rata aktivitas peserta didik selama pembelajaran, (3) rata-rata respon peserta didik terhadap pembelajaran, (4) rata-rata hasil pengamatan kemampuan guru mengelola pembelajaran, (5) analisis tes hasil belajar, (6) analisis efektivitas pembelajaran berbasis konstruktivisme dengan model kooperatif tipe TAI yang meliputi: (a) uji ketuntasan hasil belajar terhadap Kriteria Ketuntasan Minimal (KKM) menggunakan uji statistik t-test (one sample t-test), (b) uji ketuntasan klasikal, dan (c) uji pengaruh aktivitas peserta didik terhadap hasil belajar peserta didik menggunakan uji statistik regresi linier sederhana. Hasil penelitian menunjukkan rata-rata penilaian validator terhadap perangkat pembelajaran sangat baik, dan temuan lain sebagai berikut: (1) ratarata hasil belajar peserta didik sebesar 78,87 lebih dari KKM yaitu sebesar 65, (2)
} 
ketuntasan klasikal mencapai $100 \%$, rata-rata aktivitas peserta didik pada kategori sangat aktif sebesar 4,01, respon peserta didik positif , rata-rata kemampuan guru dalam mengelola pembelajaran pada kategori sangat baik sebesar 4,07, (3) aktivitas peserta didik dalam proses pembelajaran berpengaruh terhadap hasil belajar dengan kontribusi sebesar $75,1 \%$. Dengan demikian perangkat pembelajaran matematika berbasis konstruktivisme dengan model kooperatif tipe TAI pada materi segitiga di kelas IV valid dan efektif.

Kata kunci: konstruktivisme, metode pengembangan, model kooperatif, perangkat pembelajaran, time-assisted individualization

Kualitas kehidupan bangsa sangat ditentukan oleh faktor pendidikan. Peran pendidikan sangat penting untuk menciptakan kehidupan yang cerdas, damai, terbuka, dan demokratis. Kemajuan suatu bangsa dapat dicapai melalui penataan pendidikan yang baik. Upaya peningkatan mutu pendidikan itu diharapkan dapat menaikkan harkat dan martabat manusia Indonesia, maka pendidikan harus adaptif terhadap perubahan zaman. Oleh karena itu, pembaruan pendidikan harus selalu dilakukan untuk meningkatkan kualitas pendidikan nasional.

Nurhadi dan Senduk (2013) mengatakan bahwa ada tiga hal utama yang perlu disoroti dalam konteks pembaruan pendidikan, yaitu pembaruan kurikulum, peningkatan kualitas pembelajaran, dan efektivitas metode pembelajaran. Kurikulum pendidikan harus komprehensif dan responsif terhadap dinamika sosial, relevan, tidak overload (tidak memuat beban yang terlalu berat), dan mampu mengakomodasikan keberagaman keperluan dan kemajuan teknologi. Kualitas pembelajaran harus ditingkatkan untuk meningkatkan kualitas hasil pendidikan dan secara mikro, harus ditemukan strategi atau pendekatan pembelajaran yang efektif di kelas, yang lebih memberdayakan potensi peserta didik. Ketiga hal itulah yang sekarang menjadi fokus pembaruan pendidikan di Indonesia. Even (2012) mengatakan bahwa pembaruan dalam bidang pendidikan difokuskan pada pengembangan kurikulum yang baik. Tetapi hal ini belum cukup jika para guru tidak menguasai kurikulum dan tidak melakukan perubahan dalam pembelajaran di kelas.

Pembaruan pendidikan juga terjadi di dalam pendidikan matematika. Pendidikan matematika di tanah air saat ini sedang mengalami perubahan paradigma. Tujuannya adalah agar pembelajaran matematika lebih bermakna bagi peserta didik dan dapat memberikan bekal kompetensi yang memadai baik untuk studi lanjut maupun untuk memasuki dunia kerja (Soedjadi, 2014). Frykholm (2012) mengatakan bahwa perubahan dalam bidang pendidikan matematika dengan cara memperbaiki hasil lulusan, kurikulum, dan pendekatan pembelajaran di dalam pendidikan matematika melalui pembaruan dalam pedoman kurikulum nasional.

Proses pembelajaran matematika yang dilaksanakan guru di kelas menjadi persoalan yang sangat menarik untuk didiskusikan, sebab pembelajaran bermakna yang diharapkan dapat meningkatkan kemampuan berpikir logis peserta didik dan sikap positif terhadap matematika sangat jarang dilakukan, yang ada hanya proses penghafalan konsep-konsep matematika. Akibatnya beberapa hasil penelitian menunjukkan bahwa hasil belajar peserta didik sangat tidak memuaskan. Rendahnya hasil belajar matematika disebabkan oleh beberapa faktor, antara lain (1) tuntutan kurikulum yang lebih menekankan pada pencapaian target, artinya semua bahan harus selesai diajarkan dan bukan pemahaman peserta didik terhadap konsep-konsep matematika, (2) perangkat pembelajaran yang tersedia tidak lengkap dan jumlahnya sangat terbatas sekali, (3) guru memiliki kepercayaan yang rendah terhadap peserta didik, sehingga akan sulit bagi guru mempercayakan 
proses pembelajaran pada aktivitas peserta didik, seperti diskusi, mengemukakan ide, menemukan sendiri konsep matematika. Guru akan cenderung mendominasi proses pembelajaran sehingga pembelajaran berpusat pada guru. Lane (2012) mengatakan bahwa di dalam kelas tradisional guru mengajar matematika menggunakan metode yang baku dan berdasarkan buku teks, dengan memberikan definisi, aksioma, dan dalil Euchid, kemudian membuktikan penggunaan dalil yang lain.

Permasalahan di atas perlu diatasi dengan cara berusaha memperbaiki pembelajaran pada peserta didik dan mengubah paradigma mengajar menjadi paradigma belajar, yaitu pembelajaran yang lebih memfokuskan pada proses pembelajaran yang mengaktifkan peserta didik. Perubahan tersebut menuntut agar guru tidak lagi sebagai sumber informasi, melainkan sebagai teman belajar. Peserta didik dipandang sebagai makhluk yang aktif dan memiliki kemampuan untuk membangun pengetahuannya sendiri, maka diperlukan pembelajaran yang berbasis konstruktivisme. Pembelajaran berbasis konstruktivisme dapat berjalan efektif, jika sesuai dengan model pembelajaran yang dipilih. Salah satu model pembelajaran yang sesuai dengan pembelajaran yang berbasis konstruktivisme adalah model kooperatif.

Model pembelajaran kooperatif dapat memotivasi seluruh peserta didik, memanfaatkan seluruh energi sosial peserta didik, dan saling mengambil tanggung jawab. Model pembelajaran kooperatif membantu peserta didik belajar setiap mata pelajaran, mulai dari keterampilan dasar sampai pemecahan masalah yang kompleks (Nur dan Wikandari, 2015). Tujuan model pembelajaran kooperatif adalah hasil belajar akademik peserta didik meningkat, dapat menerima berbagai keragaman dari temannya, dan pengembangan keterampilan social, sebab di dalam pembelajaran kooperatif dikembangkan diskusi dan komunikasi dengan tujuan agar peserta didik saling berbagi kemampuan, saling belajar berpikir kritis, saling menyampaikan pendapat, saling memberi kesempatan menyalurkan kemampuan, saling membantu belajar, saling menilai kemampuan dan peranan diri sendiri maupun teman lain. Hal ini sesuai dengan pendapat Johnson dan Johnson (2014) bahwa pembelajaran kooperatif adalah suatu hubungan dalam kelompok peserta didik yang memerlukan saling ketergantungan positif, akuntabilitas individu, keterampilan antar pribadi (kepercayaan, komunikasi, kepemimpinan, pengambilan keputusan), tatap muka dan interaksi.

Salah satu tipe dalam model pembelajaran kooperatif adalah Time Assisted Individualization (TAl). Slavin membuat model ini dengan beberapa alasan. Pertama, model ini mengkombinasikan keunggulan kooperatif dan program pengajaran individual. Kedua, model ini memberikan tekanan pada efek sosial dari belajar kooperatif. Ketiga, TAI disusun untuk memecahkan masalah dalam program pengajaran, misalnya dalam hal kesulitan belajar peserta didik secara individual (Widdiharto, 2015).

Keberhasilan seorang guru dalam pembelajaran sangatlah diharapkan. Untuk memenuhi tujuan tersebut diperlukan suatu persiapan yang matang. Suparno (Rusdi, 2015a) mengatakan bahwa sebelum guru mengajar (tahap persiapan) seorang guru diharapkan mempersiapkan bahan yang mau diajarkan, mempersiapkan alat peraga yang akan digunakan, mempersiapkan pertanyaan dan arahan untuk memancing peserta didik aktif belajar, mempelajari keadaan peserta didik, mengerti kelemahan dan kelebihan peserta didik, serta mempelajari pengetahuan awal peserta didik, kesemuanya ini akan terurai pelaksanaannya di dalam perangkat pembelajaran.

Perangkat pembelajaran matematika yang digunakan di SDN Sambiroto 02 Semarang sangat terbatas antara lain: (1) belum ada satu pun Buku Petunjuk Guru (BPG) tentang materi ajar matematika, (2) Buku Peserta Didik (BPD) yang digunakan hanya satu jenis yaitu dari Buku Sekolah Elektronik (BSE), (3) Lembar Kegiatan Peserta Didik (LKPD) yang dipakai saat ini hanya berisi ringkasan materi dan latihan soal-soal yang jumlahnya banyak sekali, (4) alat peraga matematika 
yang dimiliki juga sangat terbatas. Pembelajaran matematika di SD tersebut dilakukan dengan pembelajaran konvensional, akibatnya aktivitas peserta didik dalam pembelajaran kurang, motivasi peserta didik untuk mengikuti pembelajaran juga kurang, sehingga pemahaman konsep peserta didik terhadap suatu materi juga kurang. Rata-rata hasil belajar yang diperoleh dengan pembelajaran konvensional untuk materi segitiga di kelas IV SDN Sambiroto 02 Semarang belum mencapai KKM yang ditentukan. Bahkan dari analisis hasil UN tahun 2014/2015 untuk mata pelajaran matematika dari 40 soal yang diberikan, nilai terendah baik ditingkat rayon, kota, maupun propinsi terdapat pada soal yang berkaitan dengan segitiga. Hal ini menjadi salah satu indikasi bahwa pembelajaran konsep segitiga selama ini kurang dipahami oleh peserta didik. Keadaan inilah yang mendorong peneliti untuk memilih pembelajaran matematika berbasis konstruktivisme dengan model kooperatif tipe TAI materi segitiga di kelas IV dan membuat perangkat pembelajarannya.

Berdasarkan latar belakang di atas, maka permasalahan dalam penelitian ini adalah: (1) Bagaimana pengembangan dan hasil pengembangan perangkat pembelajaran matematika berbasis konstruktivisme dengan model kooperatif tipe TAI yang valid pada materi segitiga di kelas IV, (2) Bagaimana keefektifan perangkat pembelajaran matematika berbasis konstruktivisme dengan model kooperatif tipe TAI materi segitiga di kelas IV. Adapun tujuan dari penelitian ini adala: (1) Untuk mengembangkan dan menghasilkan perangkat pembelajaran matematika berbasis konstruktivisme dengan model kooperatif tipe TAI yang valid pada materi segitiga di kelas IV Sekolah Dasar. (2) Untuk mengetahui sejauh mana keefektifan pembelajaran dengan menggunakan perangkat pembelajaran matematika berbasis konstruktivisme dengan model kooperatif tipe TAl materi segitiga di kelas IV Dekolah Dasar.

Mudjiman (2014) mengatakan bahwa pembelajaran konstruktivisme adalah pembelajaran yang berbasis pengembangan pengetahuan baru yang dilakukan peserta didik sendiri melalui rangsangan-rangsangan yang berasal dari dunia nyata yang relevan dengan kebutuhan peserta didik untuk dibahas dan dicari jalan keluarnya.

Secara sederhana dalam mendesain proses pembelajaran berbasis konstruktivisme, sekurang-kurangnya terdapat 6 unsur (Depdiknas, 2012) yaitu: (1) penetapan masalah, sejauh mungkin guru melibatkan peserta didik, (2) mengelompokkan peserta didik dengan mempertimbangkan beberapa faktor sehingga kelompok tersebut dapat kondusif, (3) upaya menggabungkan pengetahuan yang telah dimiliki dengan pengetahuan yang akan dicari, (4) pertanyaan-pertanyaan yang terkait dengan kegiatan untuk menjawab masalah, pertanyaan ini untuk membimbing peserta didik dalam mencari dan menganalisis data dan informasi baru yang terkait dengan masalah, (5) pengkomunikasian hasil kerja kelompok dengan kelompok lain, (6) refleksi terhadap kegiatan yang telah dijalankan dalam upaya memecahkan masalah. Konsep dasar dalam pembelajaran konstruktivisme menurut Vygotsky (Nur dan Wikandari, 2015) ada dua yaitu scaffolding dan kooperatif.

Model pembelajaran kooperatif tipe TAI memiliki delapan komponen (Suyitno, 2014). Kedelapan komponen tersebut adalah sebagai berikut:

(1) Teams yaitu pembentukan kelompok heterogen yang terdiri dari 4-5 peserta didik, (2) Placement Test yaitu pemberian pre-test kepada peserta didik atau melihat rata-rata nilai harian peserta didik agar guru mengetahui kelemahan peserta didik pada bidang tertentu, (3) Student Creative yaitu melaksanakan tugas dalam suatu kelompok dengan menciptakan di mana keberhasilan individu ditentukan oleh keberhasilan kelompoknya, (4) Team Study yaitu tahapan tindakan belajar yang harus dilaksanakan oleh kelompok dan guru, memberikan bantuan secara individual kepada peserta didik yang membutuhkan, (5) Team Score and Team Recognition yaitu pemberian skor terhadap 
hasil kerja kelompok, memberikan kriteria penghargaan terhadap kelompok yang berhasil secara cemerlang dan kelompok yang dipandang kurang berhasil dalam menyelesaikan tugas, (6) Teaching Group pemberian materi secara singkat dari guru menjelang pemberian tugas, (7) Fact Test yaitu pelaksanaan tes-tes kecil berdasarkan fakta yang diperoleh peserta didik, (8) Whole-Class Units yaitu pemberian materi oleh guru kembali diakhiri waktu pembelajaran dengan strategi pemecahan masalah.

Materi pada penelitian ini adalah segitiga yang diajarkan di kelas IV dengan Kompetensi Dasar: (1) menentukan keliling dan luas daerah segitiga, (2) menyelesaikan masalah yang berkaitan dengan keliling dan luas daerah segitiga. Dalam membelajarkan materi segitiga ini membutuhkan alat peraga berupa papan berpaku. Agar pemanfaatan alat peraga dapat maksimal dan pembelajaran berjalan efektif maka membutuhkan kerja kelompok yang dikombinasi dengan pengajaran individual, peserta didik ditempatkan dalam kelompok-kelompok kecil yang beranggotakan 4-5 orang secara heterogen dan selanjutnya diikuti dengan pemberian bantuan secara individual bagi yang membutuhkan. Di dalam kerja kelompok tersebut peserta didik berusaha menemukan dan mengkonstruk sendiri konsep keliling dan luas daerah segitiga berdasarkan langkah-langkah kegiatan yang sudah tersedia dalam LKPD. Oleh karena itu pembelajaran materi segitiga ini menggunakan pembelajaran berbasis konstruktivisme dengan model kooperatif tipe TAl.

Pengembangan perangkat pembelajaran adalah suatu proses untuk memperoleh perangkat pembelajaran yang baik/valid, yang ditentukan oleh hasil validasi ahli/pakar dan uji coba lapangan (Trianto, 2014a). Richey and Nelson (Rusdi, 2015b) mendefinisikan penelitian pengembangan sebagai suatu pengkajian sistematis terhadap pendesainan, pengembangan, dan evaluasi program, proses, dan produk pembelajaran yang harus memenuhi kriteria validitas, praktikalitas, dan efektivitas. Suatu produk atau program dikatakan valid apabila ia merefleksikan jiwa pengetahuan (state-of-the-art-knowledge). Suatu produk dikatakan efektif apabila ia memberikan hasil sesuai dengan tujuan yang telah ditetapkan oleh pengembang.

Trianto (2014a) mengatakan bahwa untuk melaksanakan pengembangan perangkat pembelajaran diperlukan model-model pengembangan yang sesuai dengan sistem pendidikan. Pada penelitian ini peneliti memilih model pengembangan perangkat pembelajaran 4-D dengan pertimbangan bahwa model 4-D memiliki kelebihan jika dibandingkan dengan model pengembangan yang lain yaitu: (1) Model Dick dan Carey, model Kemp, dan PPSI merupakan model pengembangan sistem pembelajaran, sedangkan model 4-D merupakan model pengembangan perangkat pembelajaran, (2) Pada model Dick dan Carey, model Kemp, dan PPSI tidak melibatkan penilaian ahli (validasi), sedangkan pada model 4-D dalam pengembangannya melibatkan penilaian ahli sehingga sebelum dilakukan uji coba di lapangan perangkat pembelajaran telah dilakukan revisi berdasarkan penilaian, saran, dan masukan para ahli. Dengan dilakukannya validasi oleh ahli memberikan kekuatan dan nilai tambah terhadap perangkat yang dibuat, (3) Pada model 4-D uraiannya tampak lebih lengkap dan sistematis.

Model pengembangan 4-D merupakan model pengembangan perangkat pembelajaran yang dikembangkan oleh S. Thiagarajan, Dorothy S. Semmel, dan Melvyn I. Semmel. Model pengembangan 4D terdiri atas 4 tahap utama yaitu: (1) Define (Pembatasan), (2) Design (Perancangan), (3) Develop (Pengembangan) dan Disseminate (Penyebaran), atau diadaptasi Model 4-P, yaitu Pendefinisian, Perancangan, Pengembangan, dan Penyebaran.

Peneliti memilih model yang dikembangkan oleh Thiagarajan, Semmel dan Semmel yang dikenal dengan istilah 4-D yang telah dimodifikasi pada penelitian ini. Modifikasi tersebut antara lain dengan cara: (1) memperjelas urutan kegiatan yang semula tidak jelas urutannya, (2) mengganti 
istilah yang memiliki jangkauan lebih luas dan biasa digunakan oleh guru di lapangan, (3) menambahkan kegiatan yang dianggap perlu dalam pengembangan perangkat pembelajaran dan instrumen penelitian yang akan dilakukan, (4) mengurangi tahap atau kegiatan yang dianggap tidak perlu.

Hal-hal yang dimodifikasi adalah: (1) tahap disseminate (penyebaran) ditiadakan, karena sampai pada tahap ketiga yaitu pengembangan (develop) sudah diperoleh perangkat yang baik, (2) mengganti analisis konsep menjadi analisis materi, karena yang akan dikembangkan adalah perangkat pembelajaran. Selain itu materi memiliki cakupan lebih luas daripada konsep. Dalam satu materi dapat terdiri dari beberapa konsep, (3) analisis materi dan analisis tugas dilakukan bersamasama karena keduanya mempunyai hubungan yang erat sekali, (4) pada kegiatan perancangan awal, penilaian akhir, uji coba, dan analisis uji coba dilakukan cukup sekali saja, namun pada setiap selesai kegiatan dilakukan revisi yang dianggap perlu, (5) Tes Hasil Belajar dimasukkan sebagai perangkat dan instrumen penelitian, (6) dilakukan uji coba terbatas untuk mengetahui efektivitas perangkat pembelajaran. Uji coba dilakukan pada kelas yang menggunakan perangkat yang dikembangkan (kelas uji coba).

Penelitian ini difokuskan pada pengembangan perangkat yang valid dan efektif. Validasi dilakukan oleh validator, dan untuk menentukan efektivitas pembelajaran dengan perangkat pembelajaran yang telah divalidasi maka dilakukan uji coba lapangan yang masih termasuk dalam tahap pengembangan. Dengan demikian model 4-D direduksi menjadi model 3-D.

\section{METODE PENELITIAN}

Penelitian ini merupakan penelitian pengembanganyang bertujuan untuk mengembangkan dan menghasilkan perangkat pembelajaraan yang meliputi: BPG (Buku Panduan Guru), BPD (Buku Peserta Didik), dan LKPD (Lembar Kegiatan Peserta Didik). Sedangkan instrumen penelitian yang dikembangkan adalah lembar validasi perangkat pembelajaran, lembar pengamatan aktivitas peserta didik, angket respon peserta didik, dan lembar pengamatan kemampuan guru mengelola pembelajaran.

Validasi model melalui tes ketuntasan belajar siswa menggunakan siswa kelas IV Sekolah Dasar Negeri Sambiroto II. Jumlah siswa untuk kelas control 30 Orang, dan kelas eksperimen 30 orang.

Materi yang digunakan dalam penelitian ini adalah segitiga yang terdiri dari dua Kompetensi Dasar yaitu: (1) menentukan keliling dan luas daerah segitiga, (2) menyelesaikan masalah yang berkaitan dengan keliling dan luas daerah segitiga.

Langkah-langkah penelitian yang dilakukan dalam penelitian ini adalah:(1) mengembangkan perangkat pembelajaran yang terdiri dari silabus, RPP, alat peraga, BPG, BPD, LKPD, THB, (2) menyusun instrumen pengembangan perangkat yang terdiri dari: lembar pengamatan aktivitas peserta didik, lembar pengamatan kemampuan guru mengelola pembelajaran, angket respon peserta didik, (3) melakukan validasi terhadap perangkat pembelajaran (validasi dilakukan oleh pakar/ahli), (4) menganalisis hasil validasi perangkat pembelajaran, kemudian merevisi perangkat tersebut jika belum valid,(5) melakukan uji coba tes hasil belajar, (6) menganalisis hasil uji coba tes hasil belajar, (7) menerapkan perangkat pembelajaran yang sudah valid pada kelas uji coba, (8) menganalisis hasil uji coba, (9) tahap pembuatan laporan.

Prosedur pengembangan perangkat dalam penelitian ini mengacu pada model 4-D yang dimodifikasi. Adapun langkah-langkah pengembangan dari model 4-D yang sudah dimodifikasi adalah: 
(1) Tahap Pendefinisian (Define), tujuannya adalah menentukan dan mendefinisikan kebutuhan pengajaran. Langkah pendefinisian adalah sebagai berikut: (a) analisis awal-akhir, (b) analisis peserta didik, (c) analisis materi, (d) analisis tugas, (e) spesifikasi tujuan pembelajaran. (2) Tahap Perancangan (Design), bertujuan untuk merancang prototype/rancangan perangkat pembelajaran. Prototype/rancanganperangkat pembelajaran yang akan dihasilkanmeliputi rancangan awal silabus, RPP, alat peraga, BPG, BPD, LKPD dan THB. Kegiatan yang dilakukan pada tahap ini adalah: (a) pemilihan media, (b) pemilihan format, (c) desain awal perangkat pembelajaran. (3) Tahap Pengembangan (Develop), tujuannya adalah untuk menghasilkan draf perangkat pembelajaran. Kegiatan pada langkah pengembangan ini meliputi: (a) validitas ahli, (b) uji coba THB, (c) uji coba lapangan.

Sesuai dengan jenis data yang akandiperoleh dalam penilaian ini, maka instrumen penelitian yang digunakan berupa lembar validasi perangkat pembelajaran, lembar pengamatan aktivitas peserta didik, angket respon peserta didik, lembar pengamatan kemampuan guru mengelola pembelajaran, dan Tes Hasil Belajar. Data akan dikumpulkan antara lain: (a) data penilaian validator terhadap perangkat, (b) data aktivitas peserta didik, (c) data respon peserta didik, (d) data kemampuan guru mengelola pembelajaran, (e) data tentang THB.

Data yang digunakan untuk menjawab pertanyaan penelitian adalah data uji penilaian validator dan data uji coba perangkat pembelajaran yang sedang dikembangkan. Analisis data dalam penelitian ini digunakan analisis deskriptif.

Untuk menjawab apakah pembelajaran berbasis konstruktivisme dengan model kooperatif tipe TAI materi segitiga di kelas IV efektif secara statistik dilakukan uji ketuntasan hasil belajar terhadap KKM, uji ketuntasan klasikal, dan uji pengaruh aktivitas peserta didik terhadap hasil belajar peserta didik.

Tes yang sudah dinyatakan valid, kemudian dipakai untuk mengetahui perbandingan hasil belajar peserta didik terhadap Kriteria Ketuntasan Minimal (KKM) mata pelajaran matematika SDN Sambiroto 02 sebesar 65 dengan ketuntasan klasikal lebih 75\%, setelah mengikuti pembelajaran berbasis konstruktivisme dengan model kooperatif tipe TAI materi segitiga di kelas IV.

Untuk melihat tuntas tidaknya hasil belajar peserta didik secara signifikan digunakan uji statistic t-test (one sample t-test). Untuk menghitung ketuntasan hasil belajar ini digunakan uji satu pihak (pihak kanan).

Rumusan hipotesisnya adalah:

$\mathrm{H}_{0}: \mu \leq 65$ (hasil belajar kurang dari atau sama dengan KKM 65)

$\mathrm{H}_{1}: \mu>65$ (hasil belajar lebih dari KKM 65)

Untuk menghitung ketuntasan klasikal di gunakan uji proporsi $\pi$ uji satu Pihak. Rumusan hipotesis uji ketuntasan klasikal adalah:

$\mathrm{H}_{0}: \pi=75 \%$ (persentase peserta didik yang mencapai nilai KKM sama dengan $75 \%$ ).

$\mathrm{H}_{1}: \pi>75 \%$ (persentase peserta didik yang melebihi nilai KKM lebih dari $75 \%$ )

Untuk menguji hubungan linier antara aktivitas peserta didik dan hasil belajar peserta didik dilakukan dengan analisis regresi linier sederhana yang dinyatakan dengan hubungan persamaan regresi $\hat{Y}=a+b x$.

Untuk menguji kelinieran ditentukan dengan hipotesis:

$$
\begin{aligned}
& H_{0}: \beta=0 \text { di mana } \beta=\left(\begin{array}{l}
a \\
b
\end{array}\right) \text { (persamaan tidak linier) } \\
& H_{1}: \beta \neq 0 \text { (persamaan linier) }
\end{aligned}
$$


Untuk pengujian kelinieran model di atas digunakan tabel analisis varian, dengan membaca nilai signifikan, sig < 5\% $\mathrm{H}_{0}$ ditolak sebaliknya sig $>5 \%$ maka $\mathrm{H}_{0}$ diterima. Untuk mengetahui seberapa kuat aktivitas peserta didik mempengaruhi hasil belajar peserta didik dapat dilihat dari nilai $\mathrm{R}^{2}$ (koefisien korelasi). $\mathrm{R}^{2}=\frac{\Sigma\left(\hat{Y}_{1}-\overline{\mathrm{Y}}\right)^{2}}{\Sigma\left(Y_{1}-\overline{\mathrm{Y}}\right)^{2}}=\frac{J K R}{J K T}$

Dengan mengolah menggunakan SPSS kita akan diberi out put hasil perhitungan rumus di atas.

\section{HASIL PENELITIAN}

Hasil tahap pendefinisian adalah sebagai berikut: (1) Analisis awal-akhir yaitu belum tersedianya perangkat pembelajaran yang sesuai dengan pembelajaran dan berbasis konstruktivisme dengan model kooperatif tipe TAI. (2) Analisis peserta didik: penyebab rendahnya kualitas pendidikan matematika di sekolah adalah kecenderungan guru untuk memilih pendekatan pembelajaran konvensional. Pada pembelajaran ini peserta didik cenderung pasif menerima pengetahuan dari guru. Aktivitas peserta didik untuk ikut serta membangun pengetahuan pada taraf rendah. Banyak hal yang menyebabkan kecenderungan guru memilih pembelajaran dengan pendekatan konvensional di sekolah, dan ini juga merupakan penyebab rendahnya hasil belajar matematika antara lain:1) guru harus segera menyelesaikan keseluruhan materi sesuai tuntutan kurikulum, 2) perangkat pembelajaran yang tersedia tidak lengkap dan jumlahnya sangat terbatas sekali, 3) guru kurang percaya pada kemampuan peserta didik sehingga pembelajaran lebih berpusat pada guru. 4) Analisis materi: hasilnya berupa peta konsep materi segitiga.

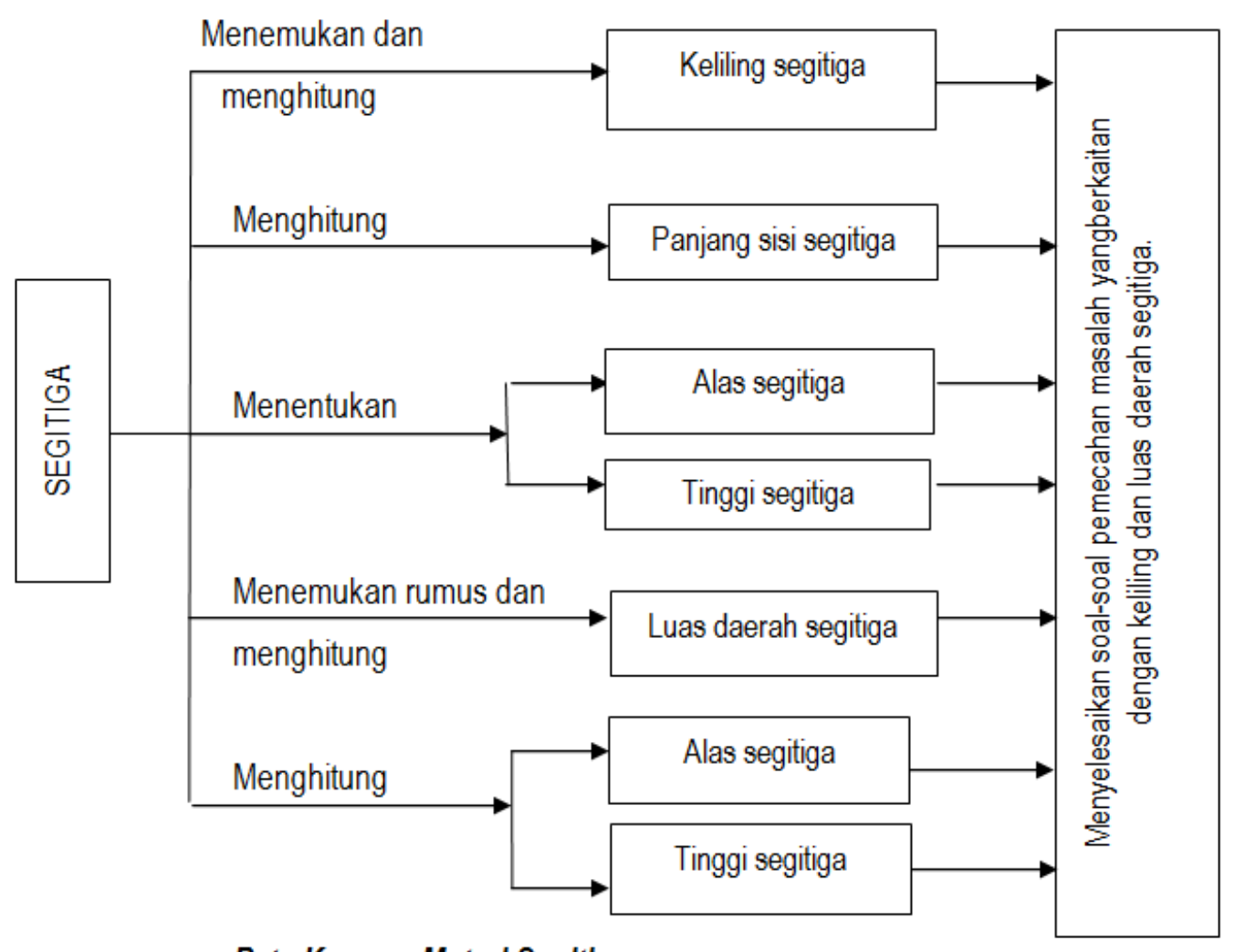

Peta Konsep Materi Segitiga 
5) analisis tugas, hasilnya berupa: (a) tugas umum terdiri dari 2 kompetensi dasar, b) tugas khusus terdiri dari 11 indikator pencapaian kompetensi, spesifikasi tujuan pembelajaran, melalui pembelajaran berbasis konstruktivisme dengan model kooperatif tipe TAI peserta didik dapat: (1) menemukan rumus keliling segitiga, (2) menghitung keliling segitiga, jika diketahui panjang sisisisinya, (3) menghitung panjang sisi segitiga jika diketahui kelilingnya, (4) menentukan alas segitiga, (5) menentukan tinggi segitiga, (6) menemukan rumus luas daerah segitiga, (7) menghitung luas daerah segitiga, (8) menghitung alas segitiga jika diketahui luas daerah segitiga dan tingginya, (9) menghitung tinggi segitiga jika diketahui luas daerah segitiga dan alasnya, (10) menyelsaikan soalsoal pemecahan masalah yang berkaitan dengan keliling segitiga, (11) menyelesaikan soal-soal pemecahan masalah yang berkaitan dengan luas daerah segitiga.

Pada tahap perancangan ini, hal-hal yang dilakukan adalah sebagai berikut: 1) Pemilihan media, media yang dipilih adalah media cetak yang terdiri dari LKPD dan BPD berbasis konstruktivisme dengan model kooperatif tipe TAI dan media benda fisik yang berupa papan berpaku. 2) Pemilihan format, pemilihan format silabus, RPP, BPG, BPD, LKPD dan Tes Hasil Belajar yang digunakan dalam penelitian ini disesuaikan dengan prinsip karakteristik, dan langkahlangkah pembelajaran berbasis konstruksitivisme dengan model kooperatif tipe TAl. Sedangkan isi pembelajaran mengacu pada hasil analisis tugas dan spesifikasi indikator pencapaian kompetensi belajar yang telah dirumuskan pada tahap pendefinisian. 3) Perancangan awal perangkat pembelajaran, Secara garis besar hasil perancangan awal perangkat pembelajaran adalah sebagai berikut: a) Silabus yang dikembangkan berisi materi segitiga yang disajikan dengan pembelajaran berbasis konstruktivisme dengan model kooperatif tipe TAI. b) Rencana Pelaksanaan Pembelajaran (RPP) yang dikembangkan untuk 3 kali pertemuan dengan alokasi waktu yang berbeda-beda. c) Alat Peraga yang dikembangkan adalah papan berpaku. Papan berpaku dibuat 2 macam, yaitu untuk klasikal dan untuk kelompok/individu. d) Buku Panduan Guru (BPG) dirancang komunikatif, memuat prinsip, prosedur, diskripsi materi pokok, dan model pembelajaran yang digunakan oleh para guru. Di dalam BPG juga memuat kunci jawaban dari soal-soal di Buku Peserta Didik. e) Buku Peserta Didik (BPD) dirancang komunikatif, yang merupakan satu paket perangkat belajar peserta didik dengan LKPD. f) Lembar Kegiatan Peserta Didik (LKPD). LKPD disusun untuk 3 pertemuan yaitu: (1) LKPD 1 menyajikan materi segitiga dan keliling segitiga. (2) LKPD 2 menyajikan materi luas daerah segitiga. (3) LKPD 3 menyajikan materi menyelesaikan masalah yang berkaitan dengan keliling dan luas daerah segitiga. LKPD memuat judul, kompetensi dasar yang akan dicapai, waktu penyelesaian, peralatan/bahan yang diperlukan untuk menyelesaikan tugas. Informasi singkat, langkah kerja, tugas yang harus dilakukan, dan laporan yang harus dikerjakan.

6) Tes Hasil Belajar (THB) disusun untuk mengetahui pemahaman peserta didik. Penyusunan instrumen tes meliputi penyusunan kisi-kisi THB, butir tes, kunci jawaban dan norma perskoran. Tes terdiri dari tes pilihan ganda. Soal pilihan ganda terdiri atas 20 butir soal yang sudah divalidasi.Tes Hasil Belajar (THB) disusun untuk mengetahui pemahaman peserta didik. Penyusunan instrumen tes meliputi penyusunan kisi-kisi THB, butir tes, kunci jawaban dan norma perskoran. Tes terdiri dari tes pilihan ganda. Soal pilihan ganda terdiri atas 20 butir soal yang sudah divalidasi.

Deskripsi tahap pengembangan (Develop), terdiri dari 1) Validasi ahli: Rerata hasil validasi ahli terhadap silabus 3,86, RPP 3,772, alat peraga 3,944, BPG 3,906, BPD 3,86, LKPD 3,822, dan THB 3,924 yang kesemuanya termasuk dalam kriteria sangat baik. 2) Uji coba Tes Hasil Belajar: (a) Soal tes uji coba yang diberikan sebanyak 20 butir dan dari hasil uji coba 20 butir soal valid, karena butir-butir soal tersebut mempunyai $r_{x y}>r_{\text {tabel. }}$ (b) Hasil perhitungan reliabilitas didapat $r_{11}=0,832$ dengan $r_{\text {tabel }}=0,334$. Karena $r_{11}>r_{\text {tabel }}$ maka soal tes uji coba tersebut reliabel. (c) Soal uji coba yang 
diberikan 20 butir dan dari hasil uji coba 20 butir soal signifikan, karena butir-butir soal tersebut mempunyai $r_{\text {hitung }}>r_{\text {tabel. (d) }}$ Soal uji coba yang diberikan sebanyak 20 butir dan dari hasil uji coba 6 butir soal mudah, 10 butir soal sedang, dan 4 butir soal sukar. 3) Uji Coba Perangkat Pembelajaran dilaksanakan 3 kali pertemuan sesuai dengan RPP yang dikembangkan. Uji coba perangkat dilaksanakan di kelas IVB SDN Sambiroto 02 Semarang tahun pelajaran 2009/2010 dengan jumlah peserta didik 30 orang. Pada uji coba ini melibatkan 5 orang guru, seorang sebagai model dan 4 orang sebagai pengamat (2 orang pengamat mengamati aktivitas peserta didik dan 2 orang mengamati kemampuan guru mengelola pembelajaran). Dalam proses pembelajaran peserta didik dikelompokkan menjadi 6 kelompok, masing-masing kelompok terdiri dari 5 orang. Dalam uji coba ini pengamat melakukan pengamatan terhadap aktivitas peserta didik selama proses pembelajaran dan kemampuan guru mengelola pembelajaran. 4) Hasil Uji Coba Perangkat Pembelajaran meliputi, a) Pengamatan aktivitas peserta didik: rata-rata aktivitas peserta didik dikategorikan sangat aktif. b) Respon peserta didik, rerata persentase respon peserta didik terhadap kegiatan pembelajaran matematika berbasis konstruktivisme dengan model kooperatif tipe TAI dan perangkat pembelajaran yang dikembangkan positif. c) Pengamatan kemampuan guru dalam mengelola pembelajaran, rerata kemampuan guru dalam mengelola pembelajaran pada kategori sangat baik sebesar 4,07.

7) Efektivitas Perangkat Pembelajaran meliputi, a) Uji Ketuntasan Hasil Belajar Peserta Didik terhadap KKM. Setelah data hasil belajar diolah dengan menggunakan SPSS 15 maka didapat informasi bahwa thitung sebesar 12,650 dan tabel sebesar 2,46 dengan rata-rata hasil tes sebesar 78,8667 dan nilai signifikan $0,000=0,0 \%<5 \%$ berarti $\mathrm{H}_{0}$ ditolak dan menerima $\mathrm{H}_{1}$ artinya hasil belajar lebih dari KKM 65. Jadi hasil belajar peserta didik telah mencapai ketuntasan terhadap KKM. b) Uji Ketuntasan Klasikal, Untuk menghitung ketuntasan klasikal digunakan uji proporsi $\pi$ uji satu pihak (uji pihak kanan). Setelah dihitung dengan rumus tersebut maka diperoleh $Z=3,16227768=$ 3,16 . Dengan taraf nyata $a=5 \%$ dari daftar normal baku memberikan $Z_{0,45}=0,3605$. Harga $Z$ nitung $=$ 3,16 lebih besar dari $Z_{\text {daftar }}=0,3605$ maka $\mathrm{H}_{0}$ ditolak dan uji sangat berarti. Ini mengatakan bahwa persentase ketuntasan klasikal sudah melampaui 75\%. c) Uji Pengaruh Aktivitas Peserta Didik Terhadap Hasil Belajar Peserta Didik. Dari tabel out put coefficients didapat koefisien arah regresi sebesar 37,719 dan konstanta sebesar -72,500. Maka hubungan persamaan regresi dapat dinyatakan dengan $\hat{Y}=-72,500+37,719 x$. Dari tabel anova didapat sig $=0,0000=0,0 \%<5 \%$ berarti $\mathrm{H}_{0}$ ditolak artinya persamaan linear. Berarti terjadi hubungan linier antara aktivitas peserta didik dan hasil belajar peserta didik. Dari out put model summary didapat $\mathrm{R}^{2}$ sebesar 0,751 . Ini berarti aktivitas peserta didik mempengaruhi hasil belajar peserta didik sebesar $75,1 \%$.

\section{PEMBAHASAN}

Rumusan masalah pada Bab I disebutkan bahwa penelitian ini mempunyai 2 masalah inti. Pengembangan perangkat pembelajaran matematika berbasis konstruktivisme dengan model kooperatif tipe TAI materi segitiga di kelas IV tersebut telah menggunakan model pengembangan perangkat pembelajaran model Thiagarajan, Semmel, dan Semmel yang dimodifikasi. Penelitian ini difokuskan pada pengembangan perangkat yang valid dan efektif. Validasi dilakukan oleh validator, dan untuk menentukan efektivitas pembelajaran dengan perangkat pembelajaran yang telah divalidasi, telah diujicobakan di lapangan yang masih termasuk dalam tahap pengembangan. Dengan demikian model 4-D direduksi menjadi model 3-D.

Pada tahap ke tiga (develop) dilakukan validasi perangkat oleh para ahli. Kegiatan ini adalah kegiatan yang penting dalam rangka menghasilkan perangkat yang valid dari segi isi dan bahasa. Semua validator merevisi dan memvalidasi satu perangkat yang sama, sehingga menjadikan 
instrumen maupun perangkat menjadi mendekati sempurna dalam tingkat kevalidannya. Peneliti menjadi lebih mengerti akan kekurangannya, baik dari segi materi pembelajaran yang disampaikan, ketelitian, konstruksi isi materi dan bahasanya. Validasi THB oleh validator adalah validasi menurut isi dan bahasanya, sedangkan validitas butir tes, reliabilitas tes, daya beda butir tes, dan taraf kesukaran butir tes dilakukan dengan cara perangkat tersebut diujicobakan di suatu kelas (IVA) yang selanjutnya hasil uji coba tes tersebut dianalisis untuk menentukan kevalidan, reliabilitas, daya beda butir tes, dan taraf kesukaran butir tes. Ini menunjukkan bahwa butir tes yang sudah valid dalam isi dan bahasanya belum tentu memenuhi kriteria valid, reliabel, memiliki daya beda butir tes, dan taraf kesukaran butir tes yang baik. Sebaliknya butir tes yang sudah memenuhi kriteria valid, reliabel, memiliki daya beda dan taraf kesukaran butir tes yang baik belum tentu valid dalam isi dan bahasanya.

Suatu tes yang baik harus valid dalam isi dan bahasanya, serta tiap butir tes harus valid, memiliki daya beda dan taraf kesukaran yang baik, serta perangkat tersebut harus reliabel. Perangkat tes pada penelitian ini, setelah dinyatakan layak dipakai oleh validator (memenuhi kriteria validitas dalam isi dan bahasa) selanjutnya diujicobakan THB tersebut. Setelah diujicobakan telah memenuhi kriteria valid, memiliki daya beda dan taraf kesukaran butir tes yang baik, serta perangkat tes tersebut telah menunjukkan reliabel.

Dalam rangka efesiensi waktu maka pembentukan kelompok peserta didik, pembagian buku peserta didik, penjelasan tentang pembelajaran matematika berbasis konstruktivisme dengan model koopertaif tipe TAI perlu disampaikan kepada peserta didik terlebih dahulu (satu minggu sebelum pembelajaran dilaksanakan di kelas).

Pemberian tugas dalam bentuk LKPD berstruktur beserta pemberian scaffolding bagi peserta didik yang membutuhkan, membuat kegiatan tanya jawab dan diskusi nampak lebih hidup. Pemberian tugas dalam bentuk LKPD dengan tingkat kesulitan yang bertahap dari mudah sampai dengan yang sulit dapat membangkitkan motivasi peserta didik. Peserta didik dapat mengerjakan suatu soal dalam LKPD, maka rasa percaya diri dan rasa kepuasan peserta didik akan meningkat, selanjutnya peserta didik termotivasi untuk mengerjakan soal berikutnya, saling bekerja sama, saling membantu antar peserta didik. Proses saling membantu dan bekerja sama antar peserta didik tersebut memunculkan tutor sebaya, dimana dengan cara dan bahasa mereka, mereka dapat membantu teman yang kurang mampu atau kurang paham atau membutuhkan dalam satu kelompok sehingga terjadilah interaksi dan hubungan yang saling menguntungkan. Hubungan yang saling menguntungkan ini dapat di lihat dari: (1) peserta didik yang kurang paham dalam suatu kelompok menjadi lebih paham, akibatnya (2) hasil belajar peserta didik dalam suatu kelompok meningkat, sehingga (3) aktivitas peserta didik dalam suatu kelompok tinggi, diskusi berjalan lancar. Keadaan ini memotivasi kelompok lain untuk melakukan hal yang sama. Muncullah kompetisi atau rasa untuk bersaing antar kelompok guna meraih hasil belajar yang lebih tinggi. Suasana belajar dengan aktivitas belajar yang tinggi, penuh tanggung jawab, kompetitif, saling bekerja sama dan diskusi yang hidup, benar-benar tercipta di dalam kelas yang menggunakan pembelajaran berbasis konstruktivisme dengan model kooperatif tipe TAl.

Diupayakan memberi kesempatan kepada peserta didik yang kurang dalam kemampuan kognitifnya untuk memaparkan hasil diskusinya. Guru harus memastikan bahwa peserta didik yang ditunjuk sudah dapat menyelesaikannya. Konsep scaffolding tetap diupayakan dalam pembimbingan guru kepada peserta didik yang memerlukan bantuan, sehingga peserta didik tidak menggantungkan diri kepada guru. 
Perangkat pembelajaran dikatakan efektif karena hasil belajar peserta didik pada materi segitiga mencapai Kriteria Ketuntasan Minimal (KKM) mata pelajaran matematika SDN Sambiroto 02 yaitu 65 , ketuntasan klasikal mencapai $100 \%$, dan ada pengaruh positif antara aktivitas peserta didik terhadap hasil belajar peserta didik sebesar $75,1 \%$. Kriteria keefektifan sudah dipenuhi. Ini menunjukkan bahwa perangkat pembelajaran yang dikembangkan oleh peneliti tersebut efektif.

Hasil penelitian ini ternyata sesuai dan mendukung hasil penelitian dari (1) Abdurrahman (2012) yang menunjukkan bahwa dengan pembelajaran konstruktivisme, terjadi peningkatan perolehan hasil belajar yang cukup signifikan, (2) Bahbahani (2014) yang mengatakan dalam penelitiannya bahwa penggunaan konstruktivisme dalam pembelajaran mempengaruhi prestasi, motivasi, dan aktualisasi diri peserta didik. Melalui pembelajaran konstruktivisme, peserta didik ditempa sehingga memahami teori dan latihan serta dapat mengaplikasikan teori dan latihan tersebut dalam dunia nyata di sekolah, (3) Hasil dari riset Sardjiman (2014) menunjukkan bahwa rata-rata skor hasil belajar peserta didik pada pembelajaran konsep luas daerah segitiga melalui pendekatan konstruktivisme pada peserta didik kelas V SDN Tegalrejo II Kota Yogyakarta meningkat, tanggapan peserta didik positif dan memuaskan.

Perangkat pembelajaran matematika berbasis konstruktivisme dengan model kooperatif tipe TAI materi segitiga di kelas IV yang dikembangkan dengan model Thiagarajan, Semmel dan Semmel yang dimodifikasi sampai tahap pengembangan menunjukkan valid dan efektif.

\section{SIMPULAN}

Berdasarkan temuan tentang proses dan hasil pengembangan, serta hasil penggunaan perangkat yang dikembangkan, dapat disimpulkan bahwa pengembangan dan perangkat pembelajaran matematika berbasis konstruktivisme dengan model kooperatif tipe TAl untuk materi segitiga di kelas IV memenuhi kriteria validitas dan efektivitas yang ditentukan.

Model ini terbukti dapat meningkatkan pemahaman siswa terhadap materi pelajaran, sehingga perlu dipertimbangkan oleh guru untuk digunakan pada materi belajar lainnya.

\section{REFERENSI}

Abdurrahman, M. \& Bintoro, T. (2012). Memahamidan menangani siswa dengan problema dalam belajar: Pedoman guru. Jakarta: Proyek Peningkatan Mutu SLTP, Direktorat Pendidikan Menengah Umum, Direktorat Jenderal Pendidikan Dasar dan Menengah, Departemen Pendidikan Nasional.

Abdurrahman. (2012). Pengembangan perangkat pembelajaran penemuan terbimbing pada topik bangun-bangun segi empat di Kelas II SLTP N 16 Pekanbaru. Tesis Magister Pendidikan. Surabaya: Program Pascasarjana Universitas Negeri Surabaya.

Arikunto, S. (2014). Dasar-dasar evaluasi pendidikan. Jakarta: Bumi Aksara.

Bahbahani, K. (2014). Inside look: An interior portrait of constructivist teacher. Kelowna: British Columbia. Diakses pada 20/03/2014 dari web http://odu.edu/educ/act/journal/vol 17 no1/bahbahani.pdf/.

Depdiknas. (2012). Materi pelatihan terintegrasi mata pelajaran matematika. Jakarta: BPPSPP SLTP.

Even, R. (2012). The development of teacher leaders and inservice teacher educators. Journal of mathematics teacher education 2:3-2.

Frykholm, A.J. (2012). The impact of reform: Challenges for mathematics teacher preparation. Journal of mathematics teacher education 2:79-105. 
Gutierrez, A. \& Jaime, A. (2012). Preservice primary teachers' understanding of the concept of altitude of triangle. Journal of mathematics teacher education 2: 253-275.

Hidayah, I. \& Sugiyarto. (2012). Workshop-1. Semarang: Universitas Negeri Semarang.

Johnson, T. R. \& Johnson, W. D. (2014). What is cooperative learning? Diakses pada 08/04/2014 dari web http://www.co-operation.org/pages/c/htm/.

Krismanto. (2013). Beberapa teknik, model dan strategi dalam pembelajaran matematika. Yogyakarta: PPPG Matematika.

Lane, E. (2012). The nature of proof in today's classrom. Journal TMEE 2: 58.

Leron, U. \& Hazzan, O. (2012). A coping perspective in mathematics education. Journal educational studies in mathematics 32: 265-292.

Mudjiman, H. (2014). Belajar mandiri (Self-Motivated Learning). Surakarta: UNS Press.

Nur, M. \& Wikandari, P.R. (2015). Pengajaran berpusat kepada siswa dan pendekatan konstruktivis dalam pengajaran. Surabaya: Pusat Studi Matematika dan IPA Sekolah. Universitas Negeri Surabaya.

Nur. (2012). Psikologi pendidikan fondasi untuk pengajaran. Surabaya: PSMS Universitas Negeri Surabaya.

Nurhadi \& Senduk A.G. (2013). Kontekstual dan penerapannya. Malang: UM Press.

Rusdi, A. (2015 a). Perangkat pembelajaran. Diakses pada 05/02/2015 dari web http://anrusmath.wordpress.com/2015/01/29/perangkat pembelajaran.

Rusdi,A. (2015 b). Model pengembangan perangkat pembelajaran. Diakses pada 20/03/2014 dari web http://anrusmath.wordpress.com/2015/01/16/pengembangan.

Sardjiman, P. (2014). Pembelajaran konsep luas daerah segi tiga melalui pendekatan konstruktivistik pada siswa kelas V SDN Tegalrejo II Kota. Yogyakarta . Diakses pada 28/02/2015 dari web http://journal.um.ac.id/index.php/jurnal-penelitiankependidikan 4/2.

Shadiq, F. (2014). Empat objek langsung matematika menurut gagne. Journal for research in mathematics education 14/1: 409.

Sinambela, N. (2014). Keefektifan Model Pembelajaran Berdasarkan Masalah (Problem based instruction) dalam pembelajaran matematika untuk pokok bahasan sistem persamaan linier dan kuadrat di Kelas X SMA 2 Rantau Selatan Sumatra Utara. Tesis. Surabaya: Program Pascasarjana Universitas Negeri Surabaya.

Slavin, E, R. (2014). Cooperative learning teori, riset dan praktek. Terjemahan Nurulita. Bandung: Nusa Media.

Soedjadi, R. (2014). PMRI dan KBK dalam era otonomi pendidikan. Buletin PMRI. Edisi III, Jan 2004. Bandung: KPPMT ITB Bandung.

Sukestiyarno,Y. L. (2013). Modul kuliah SPSS. Semarang: Program Pascasarjana. Universitas Negeri Semarang.

Suyitno, A. (2014). Pembelajaran inovatif (PLPG sertifikasi guru dalam jabatan tahun 2008). Semarang: Universitas Negeri Semarang.

Tam, M. (2012).Constructivism, instructional desain, and tehnologi. Journal education technology and society 3: 2.

Trianto. (2014 a). Model pembelajaran terpadu dalam teori dan praktek. Jakarta: Prestasi Pustaka.

Trianto. (2014 b). Model-model pembelajaran inovatif berorientasi konstruktivisme. Jakarta: Prestasi Pustaka. 
Widdiharto. (2015). Paket pembinaan penataran model pembelajaran matematika dengan pendekatan kooperatif. Yogyakarta: PPPG Matematika.

Widyantini. (2014). Model pembelajaran matematika dengan pendekatan kooperatif. Yogyakarta: Diklat PPPG Matematika.

Winkler, L.A. (2012). Exploring perimeter and area with $4^{\text {th }}$ Graders. TMME 1: 14. 